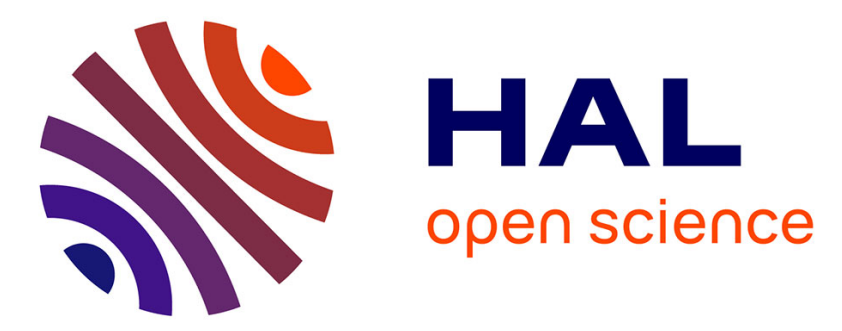

\title{
Spatial analysis of coastal chalk cliff falls in Upper Normandy (France) from Veules-les-Roses to Le Treport (2002-2009)
}

Pauline Letortu, Stéphane Costa, Emmanuel Bonnet

\section{- To cite this version:}

Pauline Letortu, Stéphane Costa, Emmanuel Bonnet. Spatial analysis of coastal chalk cliff falls in Upper Normandy (France) from Veules-les-Roses to Le Treport (2002-2009). Revue Internationale de Géomatique, 2014, 24 (3), pp.335-354. 10.3166/rig.24.335-354 . hal-01071427

\section{HAL Id: hal-01071427 \\ https://hal.science/hal-01071427}

Submitted on 25 Dec 2020

HAL is a multi-disciplinary open access archive for the deposit and dissemination of scientific research documents, whether they are published or not. The documents may come from teaching and research institutions in France or abroad, or from public or private research centers.
L'archive ouverte pluridisciplinaire HAL, est destinée au dépôt et à la diffusion de documents scientifiques de niveau recherche, publiés ou non, émanant des établissements d'enseignement et de recherche français ou étrangers, des laboratoires publics ou privés. 


\title{
Spatial Analysis of Coastal Chalk Cliff Falls in Upper Normandy (France)
}

\author{
From Veules-les-Roses to Le Treport (2002-2009)
}

\author{
Pauline Letortu ${ }^{1}$, Stéphane Costa ${ }^{1}$ and Emmanuel Bonnet ${ }^{2}$ \\ 1. Laboratory LETG Caen-Geophen, University of Caen Basse-Normandie \\ Esplanade de la Paix, 14000 Caen, France \\ pauline.letortu@unicaen.fr, stephane.costa@unicaen.fr
}

2. Laboratory IDEES Caen, University of Caen Basse-Normandie Esplanade de la Paix, 14000 Caen, France

emmanuel.bonnet@unicaen.fr

\begin{abstract}
Résumé. Les éboulements/écroulements de falaises en Haute-Normandie sont fréquents et connaissent une répartition spatiale et temporelle spécifique. De 2002 à 2009, l'association ESTRAN (Espace Scientifique et Technique des Ressources Aquatiques et de la Navigation) a conduit un inventaire hebdomadaire des éboulements/écroulements entre Veules-les-Roses et Le Tréport (37,5 km). Au total, 331 événements datés, localisés et cubés furent recensés. Cette base de données est remarquable par la durée et la répétitivité des levés. L'approche géographique et de statistiques spatiales adoptées (analyse spatiale) visent à déterminer et à comprendre la répartition spatiale et temporelle des éboulements/écroulements de falaises crayeuses. Ainsi, la cartographie exhaustive des événements met en évidence qu'entre Veulesles-Roses et Le Tréport, ces derniers se concentrent au cap d'Ailly. Par ailleurs, cette cartographie montre l'existence d'une grande variété de cinématiques d'éboulements/écroulements. Cela s'explique notamment par des caractéristiques lithologiques favorables au déclenchement des mouvements particulaires et de masse. Grâce à la combinaison des statistiques centrographiques, des fonctions $K$-Ripley et L-Besag, ainsi que du lissage par la méthode des noyaux, nous avons pu identifier : (1) la forte polarisation des éboulements/écroulements au cap d'Ailly, (2) les échelles d'organisation des localisations d'éboulements/écroulements par année hydrique; (3) les zones à éboulements/écroulements massifs et nombreux. Ces informations sont fondamentales pour une meilleure compréhension $d u$ fonctionnement du milieu étudié mais également pour la mise en place d'outils de prévention du risque.
\end{abstract}

Abstract. Coastal chalk cliff falls in Upper Normandy (France) are frequent and have specific spatial and temporal distributions. From 2002 to 2009, the ESTRAN organization (Scientific and Technical Space of Aquatic Resources and Navigation) conducted a weekly inventory of 331 cliff falls (location, volume, and date) between Veules-les-Roses and Le Treport (37.5 $\mathrm{km}$ ). An amount of 331 falls was counted (date, location, measures of fall deposit). This 


\section{RIG. Volume $24-n^{\circ} 3 / 2014$ AR_entetegauche}

database is remarkable because of the duration and high frequency of field surveys. The geographical and spatial statistics (locational analysis) methods used in this study aim to determine and understand the spatial and temporal distributions of coastal chalk cliff falls. Exhaustive cartography of such falls thus highlights the cap d'Ailly sector as being the most sensitive to an erosive dynamic along the coast from Veules-les-Roses to Le Treport. Furthermore, this cartography stresses many types of fall kinematics. This can be partly explained by lithological characteristics may predispose mass and particle movements. Using the combination of centrographic statistics, Ripley's K-function, Besag's L-function and kernel density, we have identified: (1) high cliff fall polarization at cap d'Ailly; (2) organization scales of fall locations per water year; (3) areas of massive and numerous falls (fall hazard areas). This information is essential for a better understanding of the working of the studied area and also for the set up of risk prevention tools.

MoTS-CLES : Éboulements/écroulements, falaise crayeuse, analyse spatiale 


\section{Introduction}

Coastal chalk cliffs in Upper Normandy, most often represented by the emblematic arch of Etretat, are fast erosion cliffs. The average cliff retreat rate was about $21 \mathrm{~cm} / \mathrm{yr}$ between 1966 and 1995 (Costa et al., 2004). This retreat is threatening amenities built too close to the coastline (Criel-sur-Mer, for example). A better understanding of this rocky coast erosion is therefore necessary.

A non-profit organization, ESTRAN (Scientific and Technical Space of Aquatic Resources and Navigation), has created a significant and unique database of cliff falls. Thanks to close collaboration between ESTRAN and the laboratory LETG Caen-Geophen, we have performed a spatial analysis from a large database for the segment of coastline between Veules-les-Roses and Le Treport from 2002 to 2009.

This coastline has significant issues. Many houses are located too close to the cliff top and in summer the beaches are occupied by many tourists. Because the spatial and temporal functioning remains poorly understood, the hazard "fall" is a main risk and may lead to fatalities as in other coastlines (death of a woman trapped by huge fall in July 2012 in Burton Bradstock, Dorset).

This work was implemented in order to gain a better understanding of the spatialization of cliff fall locations in respect to years in order to understand what may be predisposing factors on the occurrence of cliff falls in Upper Normandy. This work will be useful in identifying cliff fall hazard areas and thus may improve risk prevention.

To reach our objective, we studied the spatial and temporal distributions of 331 cliff falls (ESTRAN inventory). This work culminated in the use of locational analysis methods in order to gain a better understanding of the dynamics of coastal chalk cliff falls in Upper Normandy.

\section{Context}

The coastline segment surveyed by the non-profit organization ESTRAN stretches from Veules-les-Roses to Le Treport (Figure 1). Geologically, this area corresponds to the north-western termination of the Parisian Basin. The plateau of Upper Normandy and Picardy (and therefore its cliffs) is composed of Upper Cretaceous chalk (dating from Cenomanian to Campanian), which is more or less resistant to weathering and influences the rate of retreat. Residual formations with flint and quaternary lœss cover this karstified chalk.

Main tectonic deformations in NW-SE directions result in the outcrop of various geological chalk strata. The cliffs are mainly formed of Senonian white chalk, rich in flint (Coniacian, Santonian, and locally Campanian). At first glance, this chalk appears homogeneous but in reality it contains more complex details (Juignet and Breton, 1992; Laignel 1997). Coniacian chalk is present between Antifer and SaintValery-en-Caux and also between Dieppe and Le Treport. Santonian chalk is to be found in a continuous way in the central part of the cliff line from Saint-Valery-en- 
Caux to Puys (east of Dieppe). Campanian chalk is locally present from Quiberville to Pourville. Grey-white Turonian chalk, containing clay and little or no flint, outcrops from Antifer to Etretat, from Fecamp to Eletot, and from Puys to Le Treport. Its furthest extension is located at Penly. Locally, at the base of the cliffs at Antifer and Etretat, and to the east of Fecamp, Cenomanian chalk protrudes. These chalks are heterogeneous, sometimes rich in detrital components (clay and quartz) and can be glauconitic or nodular. An approximately $10 \mathrm{~m}$ thick cover of sandy and clayish sediments of palaeogene origin can be found at the cliff top at cap d'Ailly, Sotteville and Bois de Cise (figure 1).

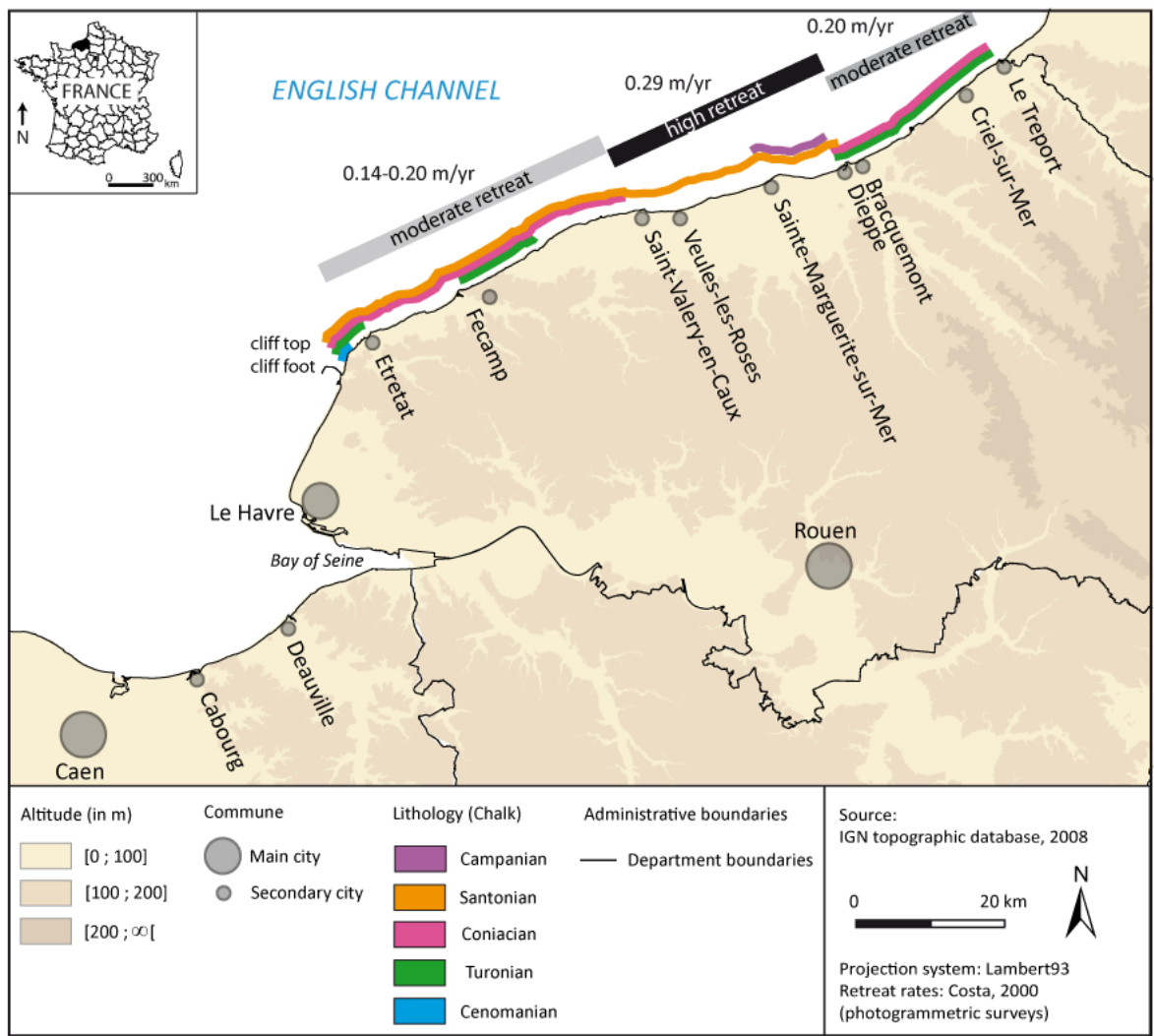

Figure 1: Geological chalk layers along the section of the Upper Normandy coast and retreat rates (from Costa, 1997, 2000; Laignel, 2003)

\section{Background}

The evolution of cliff retreat is an important issue in coastal studies. The retreat rate is often considered a good indicator of coastal evolution. The mean rate of retreat of the Upper Normandy cliff line was approximately $6 \mathrm{~m}$, i.e. a retreat speed 
of $21 \mathrm{~cm} / \mathrm{yr}$ (Costa et al., 2004). Results of this pioneering quantitative work highlight the link between lithology and the speed of retreat (figure 1). Where Santonian chalk outcrops at the foot of the cliff, retreat is the fastest.

However, a retreat rate is an average over a time-period, whereas cliff retreat is episodic. In comparison with cliff top retreat studies, few studies have been done on coastal chalk cliff falls (except Costa, 2004; Duperret et al., 2004, Genter et al., 2004). This can be explained by the difficulty encountered in obtaining the precise date of falls over a long period of time (Genter et al., 2004). In making a study of cliff falls observed from cliff face, it is possible to monitor cliff face evolution. Its evolution provides more information about the pattern of the cliff evolution and the processes potentially involved in the triggering of coastal chalk cliff falls (Young et al., 2009).

Spatial analysis methods were mainly developed in geology, agronomy, hydrology and climatology (e.g. Moussa, 1993; Rigon et al., 1994; Cudennec, 2000) then in rural, urban and physical geography (Griffin, 1973; Haggett, 1973; Taylor, 1977; Beguin, 1979; Newbury, 1980; Douguédroit, 1981; Marchand, 1981; Dauphiné, 1991, 1995; Hubert-Moy et Launay, 1997; Delahaye, 2002). For the study of landslides, methods of spatial analysis have been used like susceptibility indexes, $\chi^{2}$ test (Carrara et al., 1991; Guzzetti et al., 1999; Thiery, 2007). Study of fall distribution thanks to spatial analysis methods is new because continuous inventory of falls is very rare.

\section{Methods}

\subsection{Method of cliff fall inventory}

Since 2002, the "Service Littoral", a special branch of the non-profit organization ESTRAN, has conducted a weekly inventory of cliff falls (with location, volume, and date of falls). For each event, photographs and measurements were taken and gathered on an index card (figure 2). 


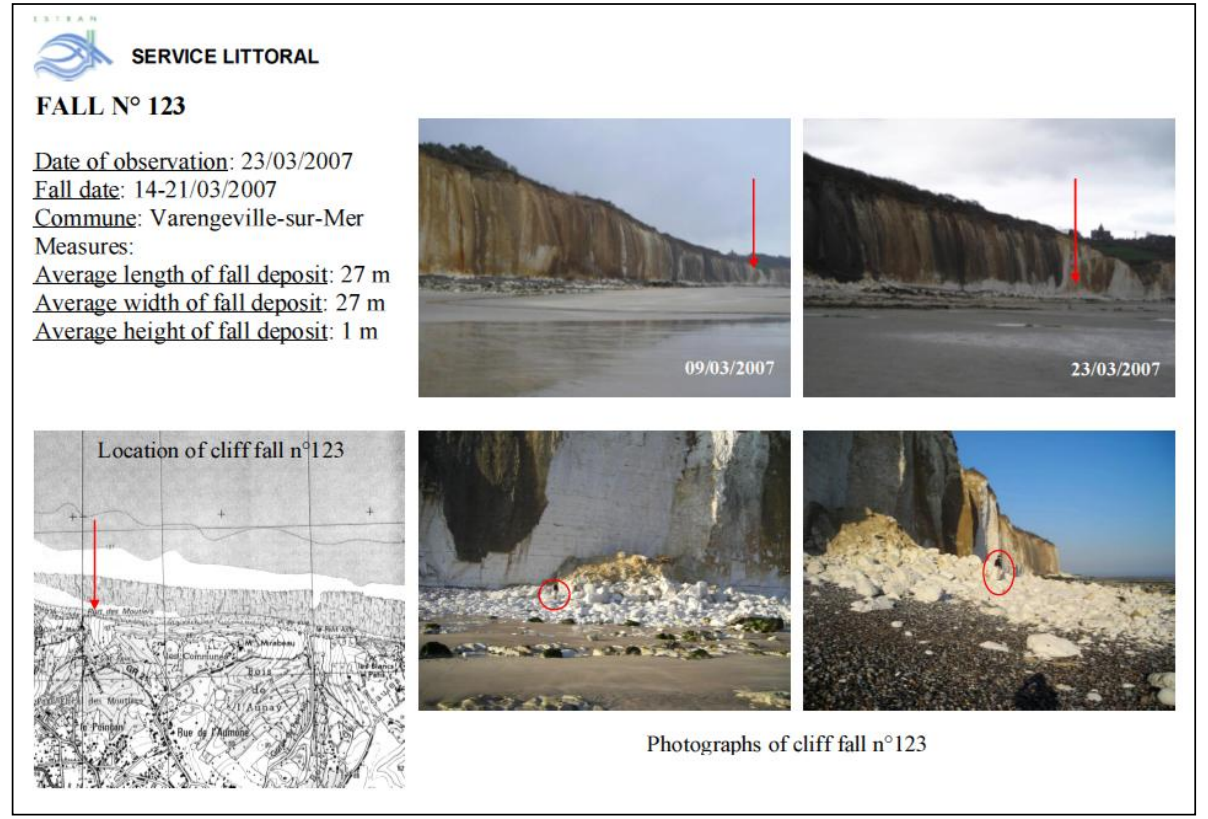

Figure 2: Index card created by the non-profit organization ESTRAN for fall number 123 observed in April 2007

The term "fall", used on this index card and in this paper, refers to a general term to describe coastal cliff « rock fall» that moves coherent rock (Varnes, 1978) (chalk in our study area). We do not make a distinction between fallen volumes and kinematics of falls (figure 3).

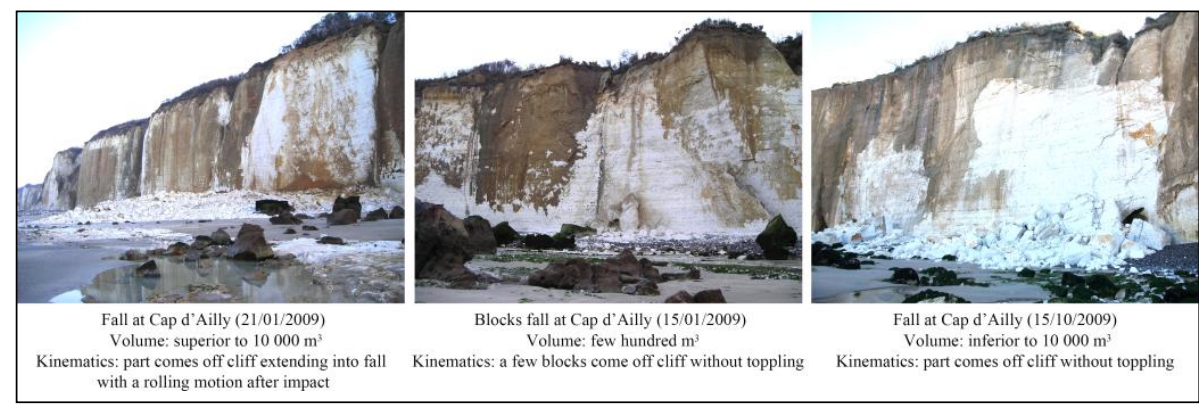

Figure 3: Various types of fall coming under the general term of fall

From 2002 to 2009, the "Service Littoral" used two methods for its inventory. From 2002 to 2003, cliff falls were observed using photographs from fixed 
observation points along $37.5 \mathrm{~km}$ of coastline. Using these photographs, some falls could be collected but small ones were often overlooked. The scale of photographs may be inappropriate for small fall observation.

Therefore, methods have evolved since 2005. The study area was reduced to 12 $\mathrm{km}$ from Sainte-Marguerite-sur-Mer to Bracquemont. This refocusing of the study area allowed the "Service Littoral" to walk along the base of the cliff over a distance of $6 \mathrm{~km}$ (half of the study area) (figure 4). This new method was used in addition to the photographs taken from fixed observation points and provides a more comprehensive inventory, especially for small cliff falls.

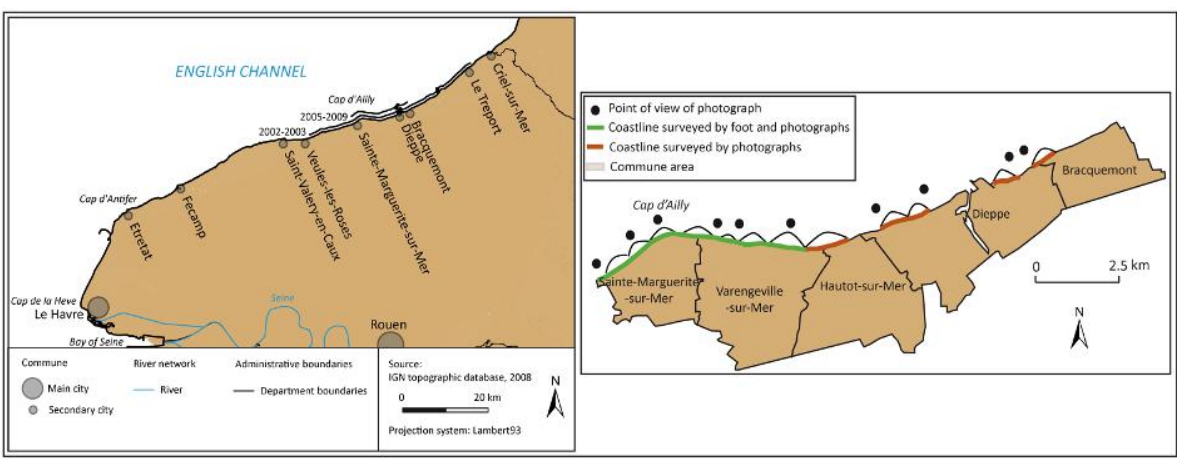

Figure 4: Study areas for the cliff falls inventory

The originality of this database lies in:

- The length of observation period (7 years);

- The high periodicity of readings (every week);

- The dating of discrete retreat events.

We added the calculations of fallen volume by taking into account the expansion rate. This rate is estimated at 33\% (Hénaff et al., 2002).

\subsection{Spatial approaches}

\subsubsection{Spatial approach of 331 cliff falls}

Referring to index cards created by the non-profit organization ESTRAN for each fall, we have information on the location of falls. The positioning of the 331 cliff falls indicates the global distribution of falls from Veules-les-Roses to Le Treport between 2002 and 2009. The significant point is to identify areas where there are numerous cliff falls. The parameters (length, width, height) of the cliff fall deposit area are measured in the field. These parameters are used in ArcGIS v.10 (thanks to the tool "table to ellipse") to show the general shape of the cliff fall deposit and information about the kinematics of the fall. 
4.2.2. Spatial approach of 5 hydrologic years of quantification: diachronic approach

The aim of this section is to analyse the spatial distribution of cliff falls in relation to the years recorded in the inventory. In accordance with the water balance, we have partitioned the database in hydrologic year time slices (from September to August) for better time coherence of cliff fall distribution and their triggering processes (rainfall, for example). Five hydrologic years are available: 2002-2003; 2005-2006; 2006-2007; 2007-2008; 2008-2009. The start of year in September can be explained by the fact that water-balance in Dieppe is affected by its first rainfall surpluses at this period after a dry period (in summer) (figure 5).

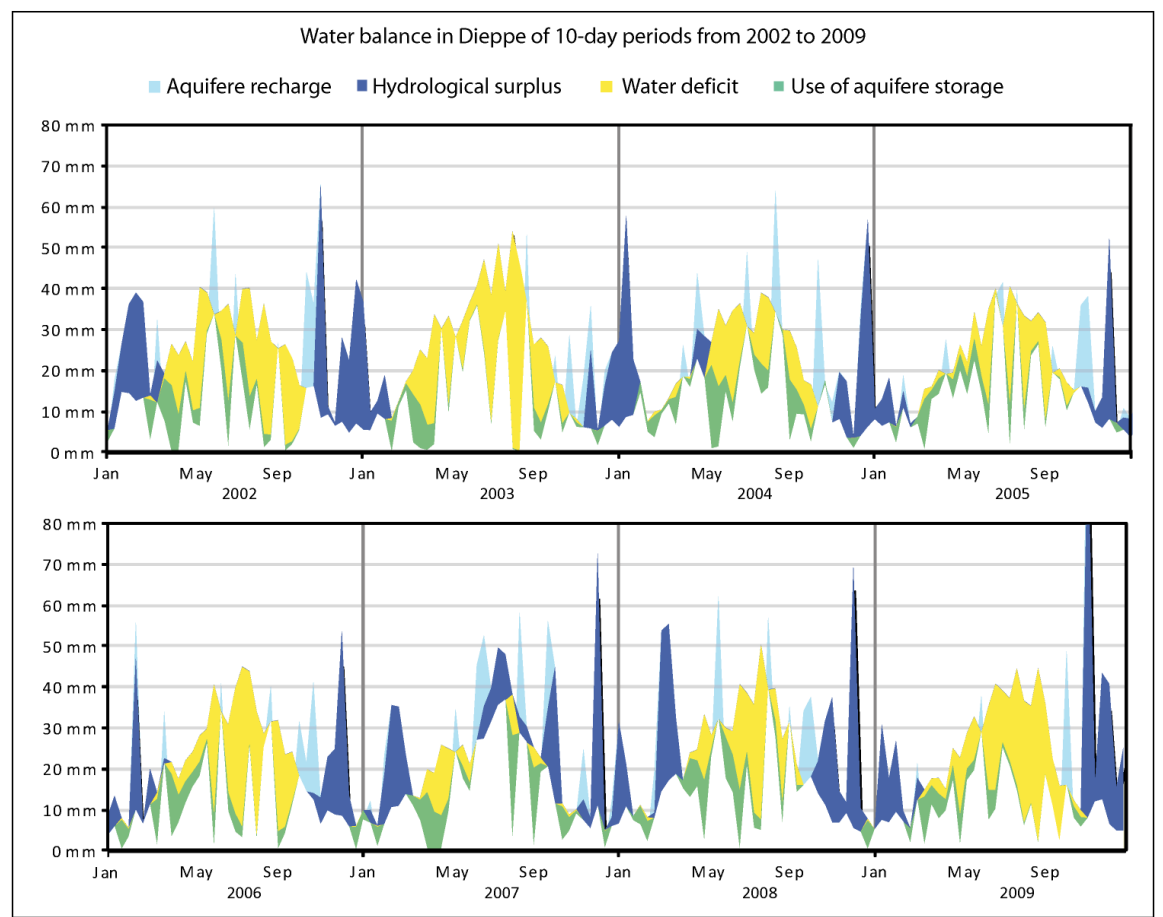

Figure 5: Water-balance from 2002 to 2009 in Dieppe (from Cantat, in press).

\subsubsection{Methods of exploratory spatial data analysis}

The aim of our research in using exploratory spatial data analysis is to collect information on spatial configuration and scale of organization of cliff falls. The objectives are to know if the spatialization of these falls is at random and if temporal distribution changes over time.

The answer to these questions is an important issue in terms of forecasting of hazard because: 
- If distribution is at random, falls obey no spatial pattern, and therefore, forecasting appears to be complex;

- If temporal distribution is regular or concentrated and varies only slightly over time, the forecasting is possible. For example, for a concentrated distribution, where the scale of clusters is defined (concentration of falls), the high hazard areas (where falls are numerous and large) and the associated predisposing factors can be identified. 2005):

Exploratory spatial data analysis can answer a number of questions (Zaninetti,

- What is the main spatial information?

- What is the organizational scale of the cliff falls spatial structure?

- What is the scale of clusters?

- How can we generalize spatial structure?

- Where are the centers of interest located?

But, first of all, it is essential to characterize the available data. Our data are a sample of "pure location data". Indeed, we cannot be sure of the exhaustiveness of cliff fall inventory because it is carried out every week and some small falls can be missed $\left(40 \mathrm{~m}^{3}\right.$ per day seem to be evacuated by sea action (Hénaff et al., 2002)).

We referred to the inductive method advocated by Zaninetti (2005), using 3 main steps: (1) global spatial statistics with centrographic statistics; (2) Ripley's Kfunction ${ }^{1}$ and Besag's correlogram (Besag's L-function); (3) local spatial statistics with kernel density method. Local Ripley was not implemented because of the recommended number of points per cluster. This minimum number is 10 points per cluster, but in our case, it is not possible to carry out the analysis with this minimum number (figure 6).

\footnotetext{
${ }^{1}$ Because we have coordinates of cliff falls in a rectangular space, with quantitative and qualitative attributes linked to cliff falls, these data fit a spatial analysis using Ripley's method. This method was mainly applied to forest studies. The theoretical basis of Ripley's method, together with an extensive bibliography, are presented in detail by many authors (e.g., Goreaud, 1995, 2000; Pélissier, 1995; Collinet, 1997; Gourlet-Fleury, 1997; Picard, 1999). This second order neighborhood analysis method which takes into account the distribution of all distances, point by point, is able to detect complex structures and to provide effective tools for interpretation. This is not the case with first order neighborhood analysis method (for example nearest neighbor) (Noël Walter, 2006).
} 


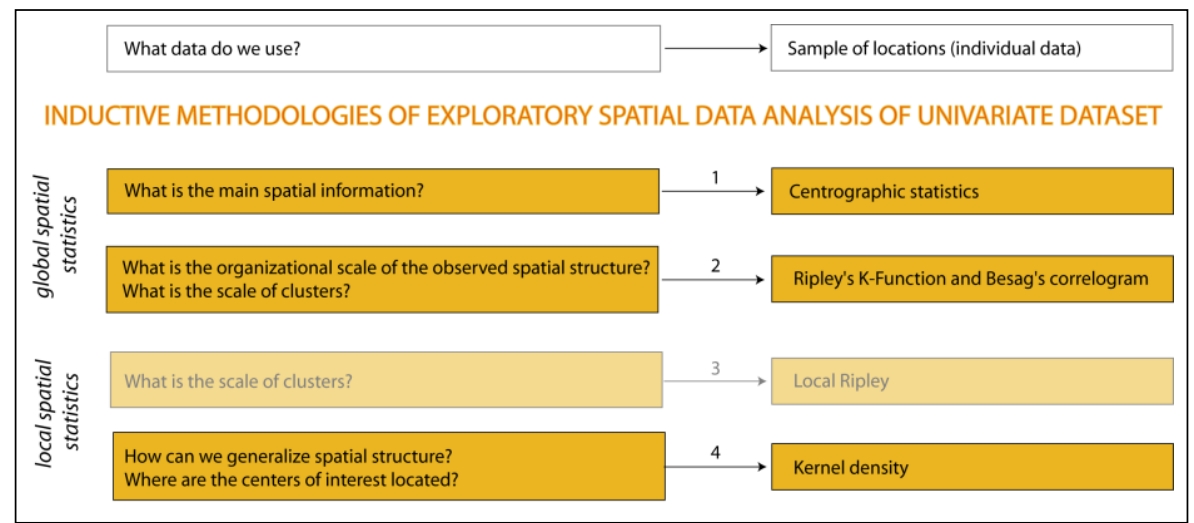

Figure 6: Methodology of locational analysis (from Zaninetti, 2005)

"It is important to specify that exploratory spatial data analysis is based on the theory of stationary point processes, therefore with quite restrictive hypotheses because of a very abstract representation of space (problems with spatial heterogeneity and edge effects ${ }^{2}$ ). It represents a significant barrier to transferring these methods from basic research to applied research. In this case, it is not so much the spatial locations that are of interest as the identification of critical or optimal locations" (Zaninetti, 2005, 202).

\subsubsection{Centrographic statistics}

The first step consists in analysing cliff falls with descriptive statistics in order to summarize the main piece of spatial information with a view to improving research hypotheses. Descriptive statistics especially have a comparative and exploratory value (Zaninetti, 2005).

Centrographic statistics are composed of central trend indicators calculated from coordinates $(\mathrm{X}, \mathrm{Y}, \mathrm{Z})$. Z may alternatively be an elevation value or an attribute quantitative value for the locations studied, on a two-dimensional plane (Lefever, 1926). In this work, it is fallen volume $\left(\mathrm{m}^{3}\right)$.

Three main indicators are used for their representativeness:

- Mean center (spatial equivalent to average),

- Standard deviational ellipse (equivalent to anisotropy),

- Standard distance (spatial equivalent to standard deviation).

These statistics are useful to identify specific sub-samples, sometimes with the need to change research hypotheses.

\footnotetext{
2 These problems and their possible solutions are discussed, for example, in Goreaud and Pélissier (1999), Zaninetti (2005), Puech (2006).
} 
The software used in this analysis is ArcGIS v.10. The same results were obtained from CrimeStat III with the network option (in order to specify that cliff falls occur along the cliff line).

4.2.3.2. Exploratory spatial data analysis based on distance: Ripley’s Kfunction and Besag's correlogram

In order to know if the distribution of falls is concentrated, exploratory spatial data analysis based on distance is performed. This analysis focuses on:

- The global spatial structure of the point set;

- Its global organization (concentrated, random, regular);

- And the scale of this organization, the second order property which identifies the existence of located clusters and their average size (Zaninetti, 2005).

To do this work, we used CrimeStatIII software to define that our set of data was organized into a network (cliff falls occur along the coastline). We performed Ripley's K-function (Ripley, 1976; 1977) on the various inventory years (from September 2002/August 2003 to September 2008/August 2009). Our samples contained more than 30 individuals (for example 34 in 2002-2003, 64 in 2008-2009) and we chose 500 simulations (computing capacity of hardware was limited) whereas 1000 simulations are recommended: "In general, it is recommended that $n$ is > 30, and that $S$ is at least 100, preferably 1000" (Noël Walter, 2006, 8).

Besag's L-function (Besag, 1977) is used with this software, because it is easier to interpret. Moreover, "corrected from size effect, L-function is suitable for comparison between several study areas or between several sets from the same area" (Zaninetti, 2005, 86).

The correlogram built afterwards with Besag's L-function is a tool used to aid decision making. It is the step prior to local spatial analysis in applied research. Indeed, if one wants to locate critical areas or those of interest in a set of pure locations, it is important to determine whether there are clusters in the set studied and what the optimal scale for locating them is.

The simulations produce a confidence interval under the null hypothesis of a homogeneous Poisson random distribution.

The upper and lower bounds of the envelope of simulated confidence are calculated. On the scale studied (up to d limit (d as distance) - to avoid the "second species risk" or power default - which for us is halfway down the shortest side of the rectangle, thus for 2002-03: $10 \mathrm{~km}$ and for 2005-09: $1.8 \mathrm{~km}$ ), when statistical L(d) is within the interval of confidence, the distribution observed is stated as consistent with a homogeneous "Poisson" random distribution.

If these statistics L(d) calculated are higher than the upper bound of the confidence interval, then distribution is concentrated in the study area. The distance to which the function is the farthest above the upper confidence interval bound of the hypothesis $\mathrm{H}_{\mathrm{o}}$ gives us a radius of research $\mathrm{d}$ of optimum concentration (Zaninetti, 2005). 
When the statistics L(d) calculated are inferior to the lower bound of the interval of confidence, distribution is regularly dispersed throughout this study area.

The evolution of the curve according to the distance enables one to draw meaningful conclusions about the general spatial structure of the study area (scale changes in the spatial structure of the set). A synthetic radius of optimum concentration can be obtained and define the best scale to observe clusters.

\subsubsection{Kernel density of cliff falls weighted by fallen volume}

Thanks to the synthetic radius of optimum concentration, it is possible to identify high hazard areas. In terms of cliff fall hazard prevention, massive cliff falls are particularly dangerous so kernel density is weighted by volume of cliff falls. The kernel density method provides an estimation of the density of cliff falls weighted by their volume. Each year, an estimation of the density of cliff falls and hazard areas is made possible.

We used ArcGIS v.10 for the kernel density method, using quadratic function. It is an interpolation method (Silverman, 1986). This tool is used to estimate a probability density from a set of located events. It is a basic form of risk analysis which can be a tool used with a view to helping decision-making for management and planning. "That is why the simple interpolation of a smoothed density surface is particularly useful in applied research" (Zaninetti, 2005, 281).

Three limits to the smoothing kernel method must be touched on. This method assumes conditions of exhaustiveness and isotropy that are rarely encountered in reality. It lacks a test procedure to validate the quality of the estimation. With ArcGIS v.10 software, it is not possible to assess the quality of interpolated density surfaces. Because of the various parameters chosen by the user (smoothing function, fixed or flexible radius of influence, output units), the assumptions are a little restrictive, but in return, this method may be very manipulative. To avoid this effect, the radius is determined by $\mathrm{K}$ and $\mathrm{L}$-functions.

\section{Results}

\subsection{Spatial approaches}

As a result of the spatial positioning of all cliff falls quantified from 2002 to 2009, the cap d'Ailly clearly appears to be the area most prone to cliff falls (Figure ). On a local scale, along the cliff foot at cap d'Ailly, almost all the cliff line was affected by at least one fall, with different spatial prints of deposit area for each cliff fall (figure 8).

Small deposit areas are mainly located at the northern edge of cap d'Ailly, whereas the western side, and especially the eastern side, are affected by more massive events (figure 8). Different kinematics of falls in this sector can be identified. 


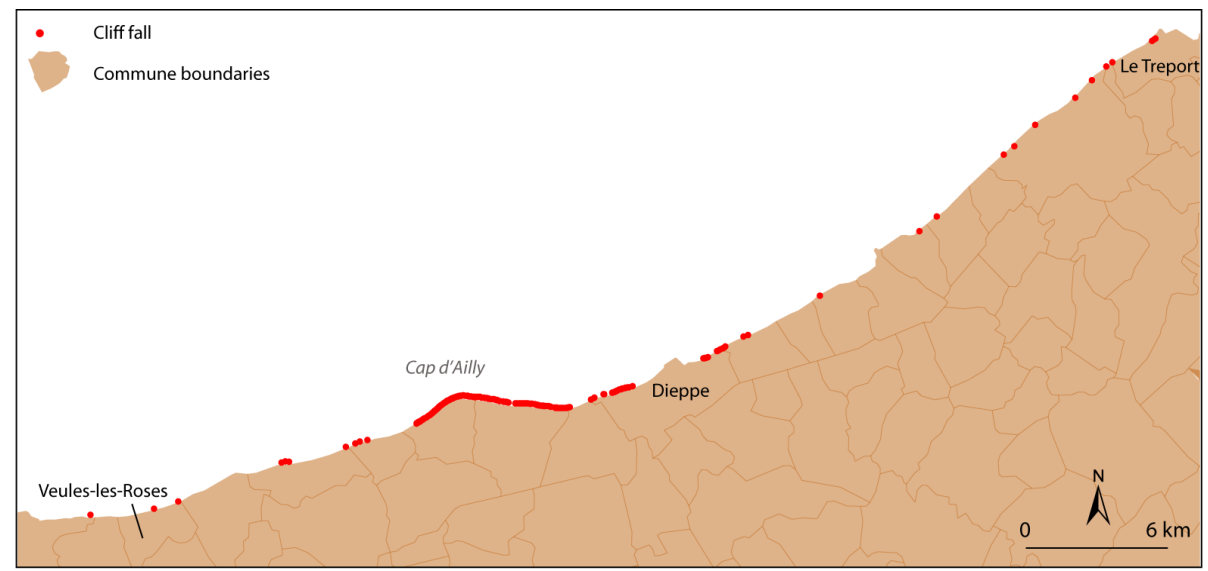

Figure 7: Cliff falls distribution from Veules-les-Roses to Le Treport (2002-2009)

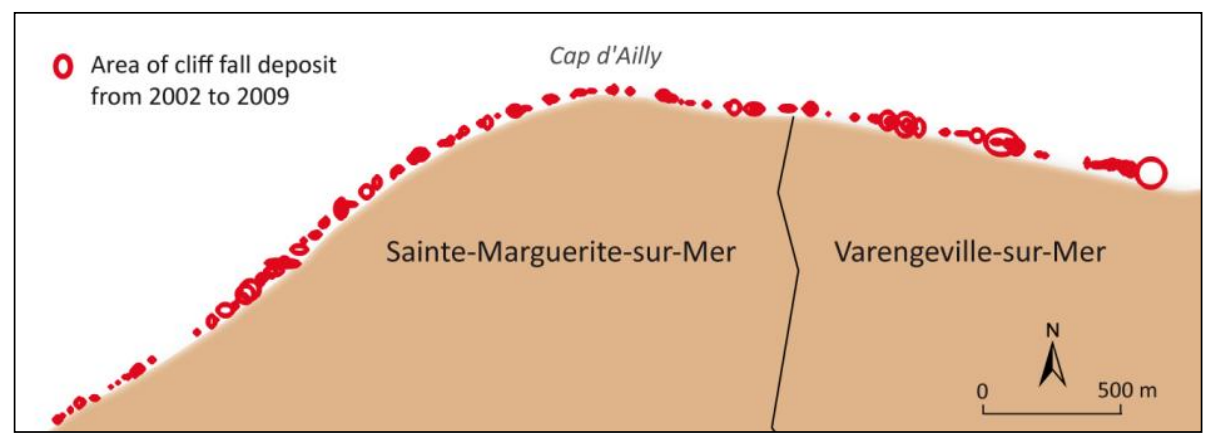

Figure 8: Cliff falls along cap d'Ailly (circles proportional to area of cliff fall deposit) (2002-2009)

This is a very dynamic area because of lithological characteristics. This part of the coast is characterized by Santonian and Campanian chalk which is particularly sensitive to weathering, covered by tertiary strata composed of clay and sand. These tertiary strata retreat rapidly because of the presence of two perched water tables (figure 9) 


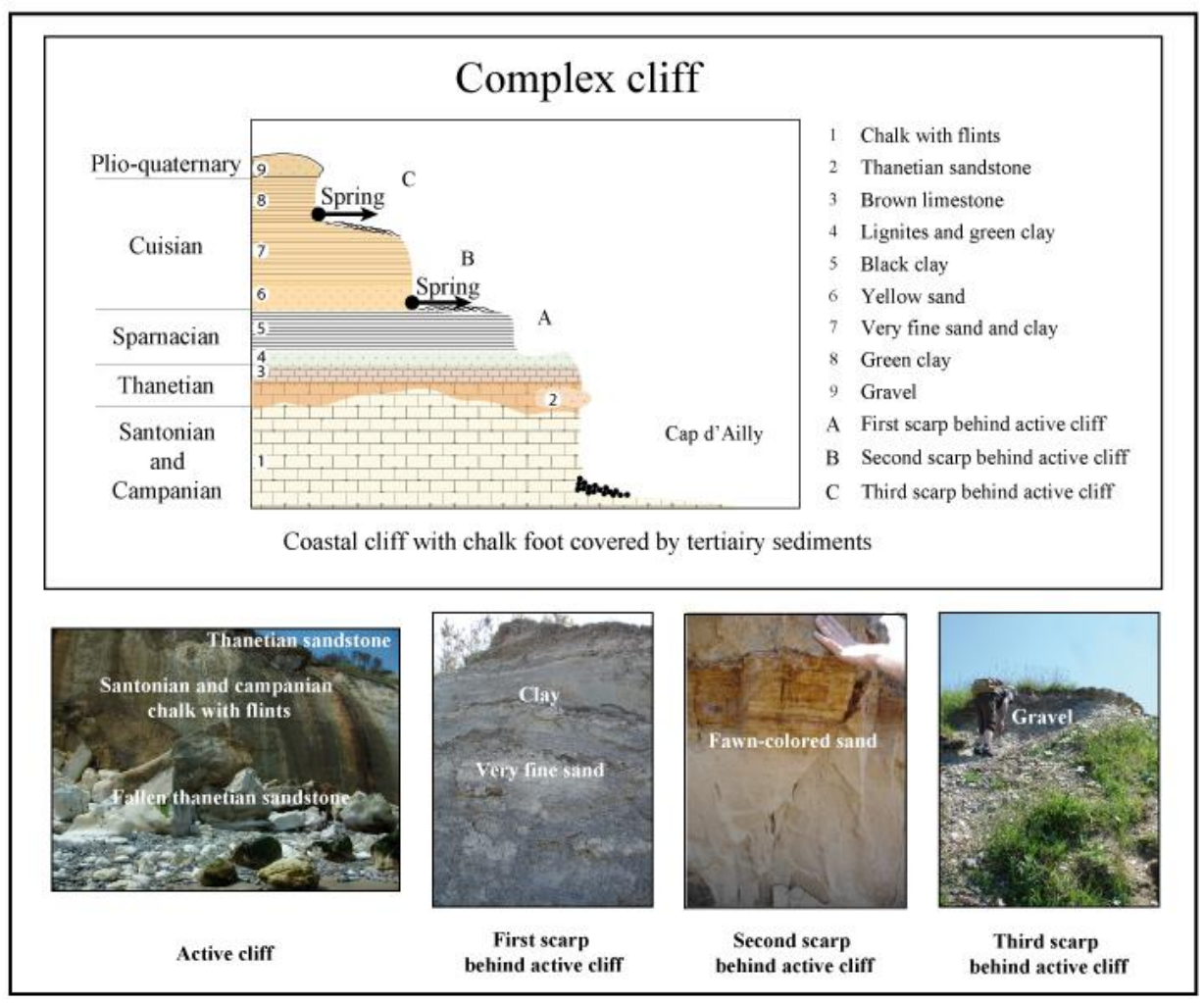

Figure 9: Lithology of cap d'Ailly

\subsection{Spatial statistics approaches}

\subsubsection{Centrographic statistics}

Standard deviational ellipses (the more elongated the ellipse, the greater the anisotropic phenomenon) reveal the specific behaviour of the hydrologic year of 2002-2003. This is due to inventory method that stretches over a coastline of 37.5 $\mathrm{km}$. Beyond this fact, a high polarization is visible with a high proportion (up to $75 \%$ ) of cliff falls included in the ellipse near cap d'Ailly for many years (which refers to high anisotropy) (figure 10). The gradual reduction in the standard distance reflects a low evolution of the fall polarization process in relation to time.

Mean centers of the whole sample for each water year demonstrate that reduction of the survey area in 2005 has not noticeably modified the mean centers of cliff falls. Mean centers are located along the eastern side of cap d'Ailly. So, contrary to what might be expected, whichever coastline was studied, a clear polarization is visible at this place. The cap d'Ailly is the location where cliff falls are the most frequent. 


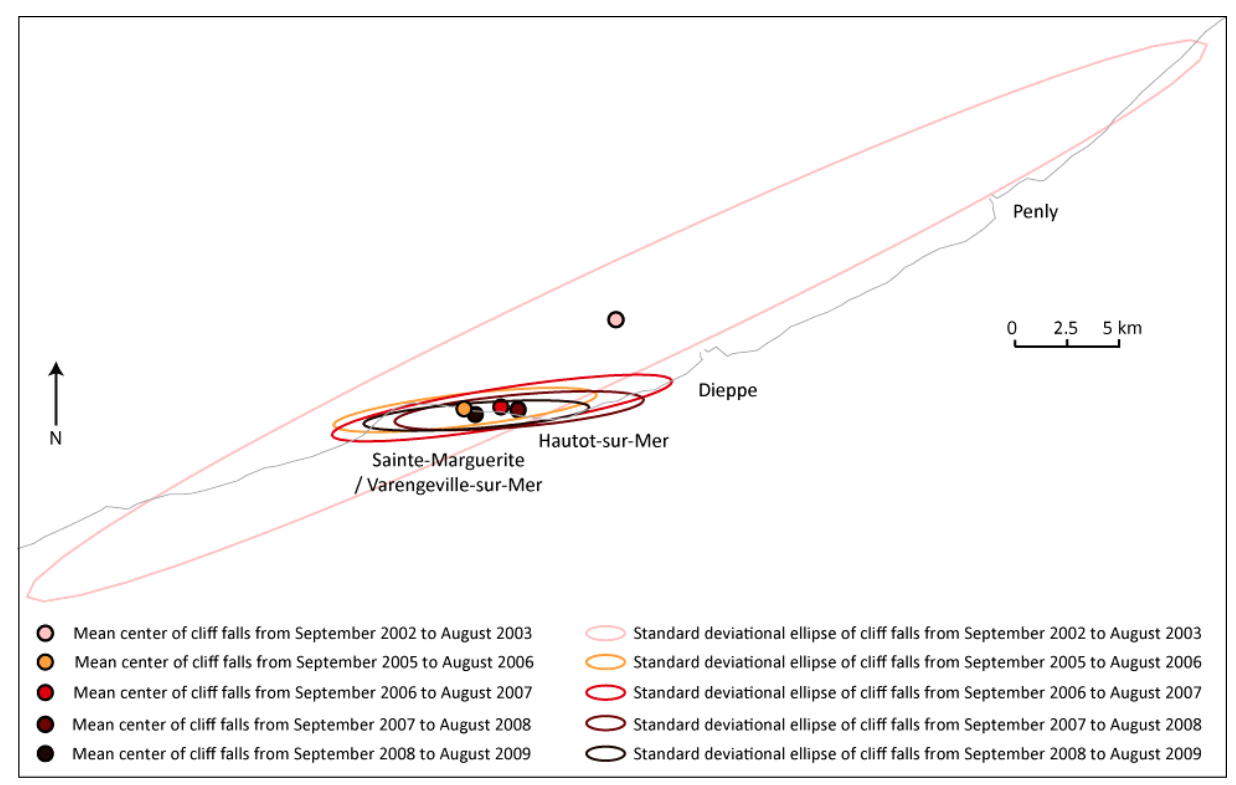

Figure 10: Centrographic statistics (mean center and standard deviational ellipse)

The changes observed over seven years are quite similar from one year to another. They do not show any particular sub-sample. Research questions may remain unchanged, as "behaviors" are homogeneous, not subject to specific cases.

\subsubsection{Exploratory spatial data analysis based on distance: Ripley's K-function and Besag's correlogram}

The function enables a comparison between different sets in the same territory (Zaninetti, 2005). This is what was done from 2002-2003 to 2008-2009 (figure 11). These different correlograms highlight that the spatial organization of cliff falls is either random or concentrated (clusters). Whatever the distance, none of the years shows a regular spatial organization of cliff falls. For the concentrated organization scale of the spatial structure observed, we notice a variability of scales in respect to years with concentration optima from 250 to $2600 \mathrm{~m}$. Ripley's and Besag's functions give a measure of the degree of spatial concentration about fall locations and average radius. The last correlogram represents the synthesis of the cliff fall set from 2002-2009, and provides a synthetic radius of optimum concentration of 800 m. 


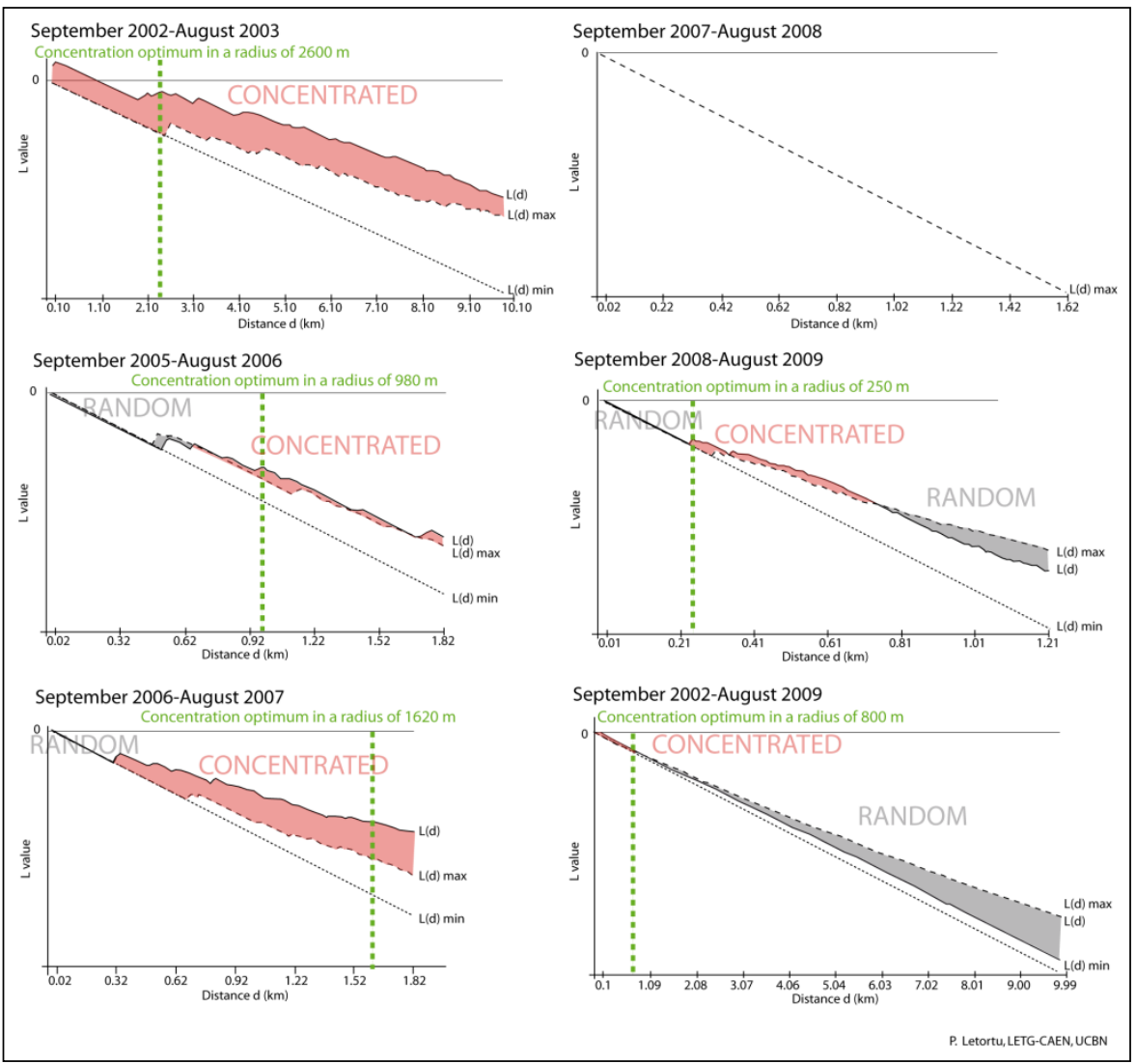

Figure 2: Besag's correlograms: global organization and organization scale of observed spatial structure

This analysis is useful with a view to improving smoothing parameters with the kernel density method (Zaninetti, 2005).

\subsubsection{Kernel density of cliff falls weighted by fallen volume}

A fixed radius for the 5 water years was chosen according to the synthetic correlogram for 2002-2009. Therefore, to compare the density of cliff falls weighted by their volume in respect to years, we used the same radius of $800 \mathrm{~m}$ (Figure 2). In this case, we can identify the evolution in the location of cliff fall hazard areas.

We can see that the distribution of hazard areas is different in respect to years. This spatial variability may be explained by the purging effect (figure 12). 


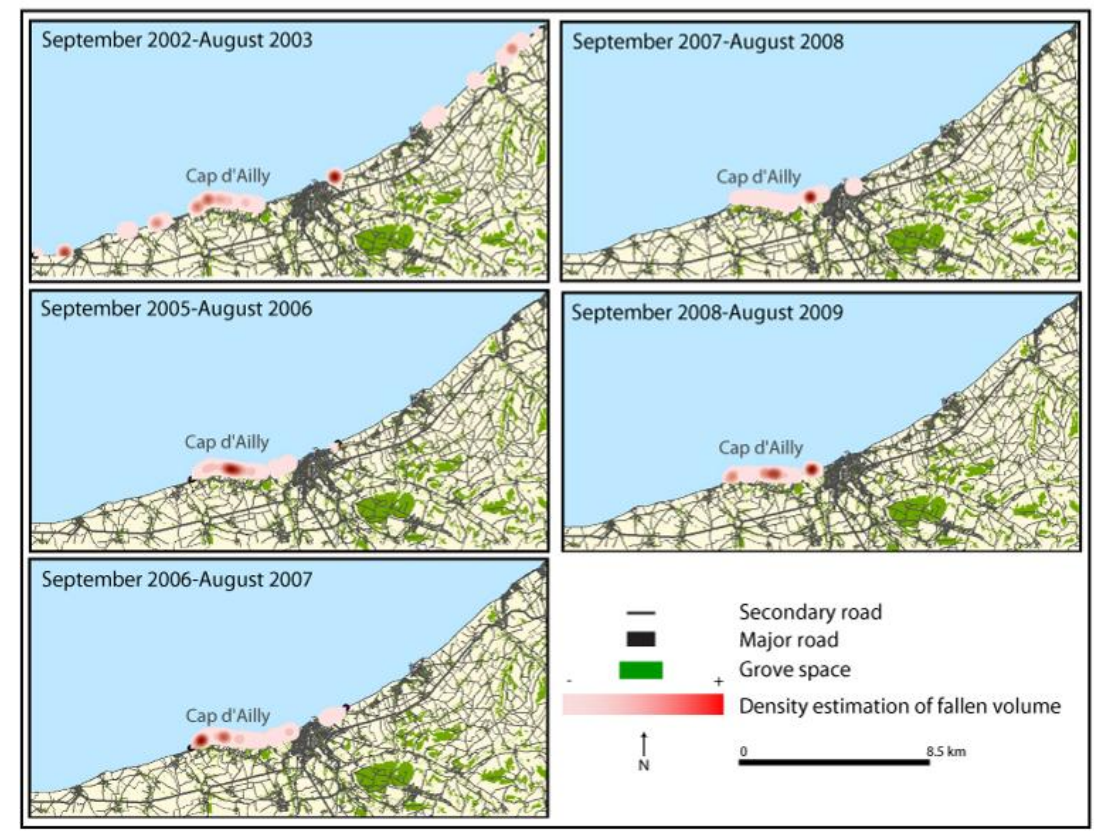

Figure 3: Kernel density with a fixed radius for the five years

However, the identification of high erosive dynamic areas with massive cliff falls is possible as at cap d'Ailly and west of Dieppe. This method thus confirms results from the naturalist method (positioning of the 331 cliff fall locations) with the identification of cap d'Ailly as a high cliff fall hazard area. This method also provides new pieces of information, i.e. the western part of Dieppe as a high cliff fall hazard area and a difference in exposure between the western and the eastern side of the cape.

\section{Conclusions}

Locational analysis and exploratory spatial data analysis used in this study of cliff falls provide new information for improving understanding of temporal and spatial distributions of coastal chalk cliff falls. This innovative approach exhibits many results. At first, the cartography of fall deposit areas stresses many types of fall kinematics due partly to lithological characteristics likely to trigger mass movements and particle movements. In addition, the method brings out high cliff fall polarization of the cap d'Ailly sector. Organization scales of fall locations per hydrologic year are highlighted and thanks to these, it is possible to identify chronic hazard areas (cap d'Ailly, west of Dieppe) where massive and numerous falls occur. Distribution of cliff falls is not at random, but spatial variability has been noticed possibly due to the purging effect. Furthermore, a difference in exposure between 
the western and eastern side of the cape can be observed. Is it linked to wave action variability (Costa et al., 2003)?

In addition to being helpful in the understanding of falls, locational analysis provides ways to learn more about hazards. The next step is to combine a vulnerability factor. Cliff fall risk areas will be highlighted in order to improve population prevention.

\section{Acknowledgements}

The authors thank ESTRAN organization for data of coastal cliff falls. We are also thankful to the reviewers for their remarks and suggestions for improvement.

\section{Bibliography}

Beguin H. (1979). Méthode d'analyse géographique quantitative. Litec, Paris, 252 p.

Besag J. E. (1977). Comments on Ripley's paper. Journal of the Royal Statistical Society B 39, p. 193-195.

Cantat O., in press. Le climat interface clé de l'écosystème. Profil Environnemental Régional de Basse-Normandie. Caen, DREAL.

Carrara A., Cardinali M., Detti R., Guzzetti F., Pasqui V., Reichenbach P. (1991). GIS techniques and statistical models in evaluating landslide hazard. Earth surface processes and landforms, vol. $16, \mathrm{n}^{\circ}$ 5, p. 427-445.

Collinet F. (1997). Essai de regroupement des principales espèces structurantes d'une forêt dense humide d'après l'analyse de leur répartition spatiale (Forêt de Paracou-Guyane). $\mathrm{PhD}$ thesis in fundamental and applied Biological Sciences, Psychology, University Lyon I.

Costa S. (1997). Dynamique littorale et risques naturels : L'impact des aménagements, des variations du niveau marin et des modifications climatiques entre la Baie de Seine et la Baie de Somme. PhD thesis in Geography, University Paris I.

Costa S., (2000). Réactualisation des connaissances et mise en place d'une méthode de suivi de la dynamique du littoral haut-normand et picard. Rapport final, Préfecture de Picardie, Contrat de Plan Interrégional du Bassin de Paris (CPIBP), June 2000.

Costa S., (2004). Le suivi des éboulements/écroulements des falaises crayeuses du Pays de Caux (Le Tréport/Veules-les-Roses) entre 2002 et 2004. Rapport final, Conseil Général de la Seine-Maritime, September 2004.

Costa S., Delahaye D., Freiré-Diaz S., Di Nocera L., Davidson R., Plessis E. (2004). Quantification of the Normandy and Picardy chalk cliff retreat by photogrammetric analysis. In: Mortimore R.N., Duperret A. (Eds.), Coastal Chalk Cliff Instability, Engineering Geology Special Publications, vol. 20, p. 139-148.

Costa S., Lageat Y., Hénaff A., Delahaye D., Plessis E. (2003). Origine de la variabilité spatiale du recul des falaises crayeuses du nord-ouest du Bassin de Paris. L'exemple du littoral haut-normand (France). Hommes et Terres du Nord, Special number 2003-1, p. $22-31$. 
Cudennec C. (2000). Description mathématique du réseau hydrographique et modélisation hydrologique. Thèse de doctorat d'Agronomie, École Nationale Supérieure Agronomique de Rennes.

Dauphiné A. (1991). Ordre et chaos en géographie physique. L'espace Géographique, vol. 3, p. 289-301.

Dauphiné A. (1995). Chaos, fractales et dynamiques en géographie. Reclus, Montpellier, $135 \mathrm{p}$.

Douguédroit A. (1981). A model of the decrease of temperature with altitude in mountains. In: European Progress in Spatial Analysis, Bennett R.J. (eds), Pion, London, p. 191-197.

Delahaye D. (2002). Approche de l'analyse spatiale en géomorphologie. Modélisation et approche multiscalaire des risques. Mémoire d'Habilitation à Diriger des Recherches, Université de Rouen, 259 p.

Duperret, A., Genter, A., Martinez, A., Mortimore, R.N. (2004). Coastal chalk cliff instability in NW France: role of lithology, fracture pattern and rainfall. In: Mortimore R.N., Duperret A. (Eds.), Coastal Chalk Cliff Instability, Engineering Geology Special Publications, vol. 20, p. 33-55.

Genter A., Duperret A., Martinez A., Mortimore R.N., Vila J.L. (2004). Multiscale fracture analysis along the French chalk coastline for investigating erosion by cliff collapse. In: Mortimore R.N., Duperret A. (Eds.), Coastal Chalk Cliff Instability, Engineering Geology Special Publications, vol. 20, p. 57-74.

Gourlet-Fleury S. (1997). Modélisation individuelle spatialement explicite de la dynamique d'un peuplement de forêt dense tropicale humide (dispositif de Paracou - Guyane française). $\mathrm{PhD}$ thesis in fundamental and applied Biological Sciences, Psychology, University Lyon I.

Goreaud F. (1995). Étude et modélisation des peuplements hétérogènes : rôle des interactions dans la structuration spatiale du peuplement. Master thesis in general Ecology and plant production, University Paris 6.

Goreaud F. (2000). Apports de la structure spatiale en forêt tempérée à l'étude et la modélisation des peuplements complexes. PhD thesis in Forest Sciences ENGREF, Nancy.

Goreaud F., Pélissier R. (1999). On explicit formulas of edge effect correction for Ripley's Kfunction. Journal of Vegetation Science, vol. 10, p. 433-438.

Griffin E. (1973). Testing the van Thünen theory in Uruguay. Geographical Review, vol. 63, p. 500-516.

Guzzetti F., Carrara A., Cardinali M., Reichenbach P. (1999). Landslide hazard evaluation: a review of current techniques and their application in a multi-scale study, Central Italy. Geomorphology, vol. 31, $\mathrm{n}^{\circ}$ 1, p. 181-216.

Haggett P. (1973). L'analyse spatiale en géographie humaine. Armand Colin, Paris, 390 p.

Hénaff A., Lageat Y., Costa S., Plessis E. (2002). Le recul des falaises crayeuses du Pays de Caux : détermination des processus d'érosion et quantification des rythmes d'évolution. Géomorphologie, vol. 8, n² 2, p. 107-118. 
Hubert-Moy L. Launay M. (1997). Approche spatiale du risque de pollution diffuse en milieu agricole intensif : application à un affluent de l'Elorn. In : Actes des deuxièmes rencontres THEO QUANT 1997. Annales littéraires de l’Université de Franche-Comté, p. 57-64.

Juignet P., Breton G., 1992. Mid-Cretaceous sequence stratigraphy and sedimentary cyclicity in the western Paris Basin. Paleogeography, Paleoclimatology, Paleoecology, vol. 91, p. 197-218.

Laignel B., 2003. Caractérisation et dynamique érosive de systèmes géomorphologiques continentaux sur substrat crayeux. Exemple de l'Ouest du Bassin de Paris dans le contexte nord-ouest européen. Professorial thesis in Geology, University Rouen.

Lefever D. (1926). Measuring geographic concentration by means of the standard deviational ellipse. American Journal of Sociology, vol. 32, $\mathrm{n}^{\circ}$ 1, p. 88-94.

Marchand J.P. (1981). Physical constraints and contemporary geography. In: European Progress in Spatial Analysis, Bennet R.J. (eds), Pion, London, p. 71-82.

Moussa R. (1993). Modélisation hydrologique spatialisée et système d'information géographique. La Houille Blanche, vol. 5, p. 293-301.

Newbury P.A.R. (1980). A geography of agriculture. Mac Donald \& Evans Ltd, Plymouth, $326 \mathrm{p}$.

Noël Walter J.M. (2006). La méthode de Ripley pour l'analyse des structures spatiales ponctuelles en Ecologie. Master thesis in Physical Geography and Planning, University Strasbourg.

Pélissier R. (1995). Relations entre l'hétérogénéité spatiale et la dynamique de renouvellement d'une forêt dense humide sempervirente (Forêt d'Uppangala - Ghâts Occidentaux de l'Inde). $\mathrm{PhD}$ thesis in fundamental and applied Biological Sciences, Psychology, University Lyon I.

Picard N. (1999). Passage d'un modèle individuel à un modèle de distribution de la dynamique forestière. Application à une forêt dense tropicale humide de Guyane française. PhD thesis thesis in fundamental and applied Biological Sciences, ENGREF, Nancy.

Puech F. (2006). Contribution à l'analyse de la localisation et de la concentration spatiale des activités industrielles. Vie \& sciences économiques, vol. 4, n 173 , p. 46-58.

Rigon R., Rinaldo A., Rodriguez-Iturbe I. (1994). On landscape self-organisation. Journal of Geophysical Research, vol. 11, p. 971-993.

Ripley B.D. (1976). The Second-Order Analysis of Stationary Point Processes. Journal of Applied Probability, vol. 13, p. 255-266.

Ripley B.D. (1977). Modelling Spatial Patterns. Journal of the Royal Statistical Society B 39, p. 172-212.

Silverman B.W. 1986. Density Estimation for Statistics and Data Analysis. Chapman and Hall, London.

Taylor P. (1977). Quantitative methods in Geography, an introduction of Spatial Analysis. Houghton Mifflin, Boston, 386 p. 
Thiery Y. (2007). Susceptibilité du Bassin de Barcelonnette (Alpes du Sud, France) aux 'mouvements de versant': cartographie morphodynamique, analyse spatiale et modélisation probabiliste. Thèse de doctorat de Géographie, Université de Caen.

Varnes D.J. (1978). Slope movement types and processes. In: Special Report 176: Landslides: Analysis and Control (Eds: Schuster, R. L. \& Krizek, R. J.). Transportation and Road Research Board, National Academy of Science, Washington D. C., January 1978.

Young A.P., Flick R.E., Gutierrez R., Guza R.T. (2009). Comparison of short-term seacliff retreat measurement methods in Del Mar, California. Geomorphology, vol. 112, p. 318323.

Zaninetti J.M. (2005). Statistique spatiale, méthodes et applications géomatiques, Hermès science, Paris. 